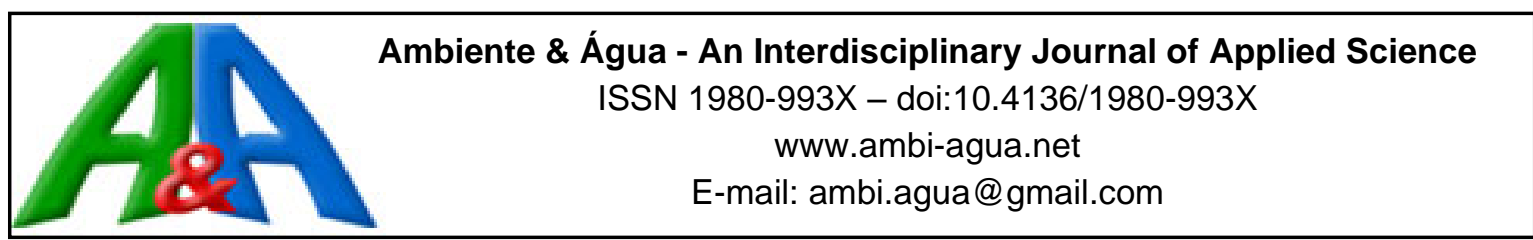

\title{
Saline waters and nitrogen/potassium fertilization combinations on physiological aspects and production of West Indian cherry
}

\author{
ARTICLES doi:10.4136/ambi-agua.2780
}

Received: 11 Aug. 2021; Accepted: 26 Oct. 2021

\section{Evandro Manoel da Silva ${ }^{1^{*} \text {; }}$; Hans Raj Gheyi ${ }^{1}$; Reginaldo Gomes Nobre $^{2}$ (D); Geovani Soares de Lima ${ }^{1}$; ; Lauriane Almeida dos Anjos Soares ${ }^{3}$; Benedito Ferreira Bonifácio 1 (ic}

\footnotetext{
${ }^{1}$ Programa de Pós-Graduação em Engenharia Agrícola. Universidade Federal de Campina Grande (UFCG), Avenida Aprígio Veloso, n ${ }^{\circ} 882$, CEP: 58429-140, Campina Grande, PB, Brazil.

E-mail: hans@pq.cnpq.br, geovanisoareslima@gmail.com, benedito_agronomo@hotmail.com

${ }^{2}$ Departamento de Ciência e Tecnologia. Universidade Federal Rural do Semi-Árido (UFERSA), Sítio Esperança II, Zona rural, CEP: 59780-000, Caraúbas, RN, Brazil. E-mail: rgomesnobre@ yahoo.com.br

${ }^{3}$ Unidade Acadêmica de Ciências Agrárias. Universidade Federal de Campina Grande (UFCG), Rua Jario Vieira Feitosa, n 1770, CEP: 58840-000, Pombal, PB, Brazil. E-mail: lauriane.soares@pq.cnpq.br

*Corresponding author. E-mail: evandroagroman@ hotmail.com
}

\begin{abstract}
This study evaluated the influence of combinations of nitrogen and potassium doses on the physiology and fruit production of West Indian cherry irrigated with waters of different salinities in the second year of cultivation. The experiment was conducted in the municipality of Pombal-PB, Brazil, in plastic containers adapted as lysimeters installed in the field, in a randomized block design, $5 \times 4$ factorial scheme corresponding to five levels of electrical conductivity of irrigation water (ECw): $0.3,1.3,2.3,3.3$ and $4.3 \mathrm{dS} \mathrm{m}^{-1}$, and four combinations of nitrogen and potassium fertilization: $70 \% \mathrm{~N}+50 \% \mathrm{~K}_{2} \mathrm{O} ; 100 \% \mathrm{~N}+75 \% \mathrm{~K}_{2} \mathrm{O} ; 130 \% \mathrm{~N}+$ $100 \% \mathrm{~K}_{2} \mathrm{O}$ and $160 \% \mathrm{~N}+125 \% \mathrm{~K}_{2} \mathrm{O}$ of the dose recommended for West Indian cherry, with three replicates and one plant per plot. The cv. 'Flor Branca' was grafted on the cv. 'Junco', between 420 and 550 days after transplanting. Nitrogen and potassium combinations did not mitigate the deleterious effects of water salinity on the physiology and fruit formation of West Indian cherry. An increase in ECw intensifies the intercellular electrolyte leakage and reduces the water potential in the branch, chlorophyll content in the leaves, $\mathrm{CO}_{2}$ assimilation rate, equatorial and polar diameters as well as the mass of fruits. Fertilization of plants with $70 \% \mathrm{~N}$ $+50 \%$ of $\mathrm{K}_{2} \mathrm{O}$, compared to the other fertilization combinations, causes less intercellular electrolyte leakage and promotes higher $\mathrm{CO}_{2}$ assimilation rates, higher chlorophyll content in leaves, and fruits of larger size and mass.
\end{abstract}

Keywords: Malpighia emarginata D. C, mineral fertilization, salt stress.

\section{Águas salinas e combinações de adubação com nitrogênio/potássio sobre aspectos fisiológicos e produção de aceroleira}

\section{RESUMO}

O objetivo do trabalho foi avaliar a influência de combinações de doses de nitrogênio e potássio sobre a fisiologia e a produção de frutos de aceroleira irrigada com água de diferentes

This is an Open Access article distributed under the terms of the Creative Commons Attribution License, which permits unrestricted use, distribution, and reproduction in any medium, provided the original work is properly cited. 
salinidades, no segundo ano de cultivo. O experimento foi conduzido no município de Pombal$\mathrm{PB}$, Brasil, em recipientes plásticos adaptados como lisímetros instalados em campo, em delineamento de blocos ao acaso, esquema fatorial 5 x 4 referentes a cinco níveis de condutividades elétricas da água de irrigação (CEa): 0,$3 ; 1,3 ; 2,3 ; 3,3$ e 4,3 dS m m $^{-1}$ e quatro combinações de adubação nitrogenada e potássica: $70 \% \mathrm{~N}+50 \% \mathrm{~K}_{2} \mathrm{O} ; 100 \% \mathrm{~N}+75 \% \mathrm{~K}_{2} \mathrm{O}$; $130 \% \mathrm{~N}+100 \% \mathrm{~K}_{2} \mathrm{O}$ e $160 \% \mathrm{~N}+125 \% \mathrm{~K}_{2} \mathrm{O}$ da dose recomendada para aceroleira, com três repetições e uma planta por parcela. Estudou-se a cv. Flor Branca enxertada sobre a cv. Junco, entre 420 e 550 dias após o transplantio. As combinações de nitrogênio e potássio não mitigam os efeitos deletérios da salinidade da água sobre a fisiologia e a produção de frutos da aceroleira. $\mathrm{O}$ aumento na $\mathrm{CEa}$ intensifica os danos às membranas celulares, reduz o potencial hídrico no ramo, teor de clorofila nas folhas, taxa de assimilação de $\mathrm{CO}_{2}$, diâmetro equatorial e polar e a massa de frutos. A adubação das plantas com $70 \%$ de $\mathrm{N}+50 \%$ de $\mathrm{K}_{2} \mathrm{O}$, em relação às outras combinações de adubação, causa menor extravasamento de eletrólitos e proporciona maior taxa de assimilação de $\mathrm{CO}_{2}$, teor de clorofila nas folhas, frutos de maior tamanho e massa.

Palavras-chave: estresse salino, fertilização mineral, Malpighia emarginata D. C.

\section{INTRODUCTION}

West Indian cherry (Malpighia emarginata D.C.) is one of the promising species in the fruit sector in the semi-arid region of Northeastern Brazil. It can be consumed fresh or processed, in the form of juices, ice cream, jams, syrups, liqueurs, fruit preserves, etc., standing out for the nutritional value of its fruits, mainly as a source of vitamin $\mathrm{C}$, anthocyanins, iron, calcium, vitamin A and B complex vitamins, resulting in great demand in the export market (Esashika et al., 2013).

Due to the adaptation to edaphoclimatic conditions, about $78 \%$ of West Indian cherry production in Brazil is concentrated in the Northeast region, and its main producers are the states of Pernambuco, Ceará, Sergipe, Paraíba and Piauí (Ibge, 2017). However, the reduction of water volume in water sources and the high concentration of salts in irrigation water may become limiting factors for the exploitation of this crop in the semi-arid region of Northeastern Brazil (Lima et al., 2019a).

In this region, salt stress stands out among the abiotic stresses that most hamper the growth and production of agricultural species (Carneiro et al., 2002), due to the reduction in the osmotic potential of the soil solution and the occurrence of nutritional imbalance and physiological disorders through metabolic alterations such as oxidative stress (Mendes et al., 2011), caused by the effect of the high concentration of toxic ions, especially $\mathrm{Na}^{+}$and $\mathrm{Cl}^{-}$, in the protoplasm (Flowers et al., 2014), which also promote structural changes and rupture of cell membranes (Ferraz et al., 2015).

Studies investigating the effect of irrigation water salinity between 0.6 and $3.8 \mathrm{dS} \mathrm{m}^{-1}$ has shown harmful effects of salt stress on photosynthesis, photochemical efficiency, water relations, growth, and production components of West Indian cherry (Sá et al., 2018a; 2018b; 2019; Lima et al., 2019a). Some studies have shown that the increase in potassium doses mitigated the deleterious effect of salt stress on plant growth, the number of fruits and total weight of fruits per plant (Lima et al., 2019b) and of nitrogen and phosphorus proportions on photochemical efficiency and growth (Sá et al., 2018a), photosynthetic pigments (Sá et al., 2018b), and the number of fruits per plant (Sá et al., 2019).

These positive effects may be related to the decrease in $\mathrm{Na}^{+} / \mathrm{K}^{+}$and $\mathrm{Cl}^{-} / \mathrm{NO}_{3}{ }^{-}$ionic ratios in plant tissues as a function of increased $\mathrm{N}$ and $\mathrm{K}$ doses, hence offsetting the effects of nutritional imbalance and salt stress on physiological aspects, growth, and production of plants (Andrade Junior et al., 2011). Moreover, an adequate concentration of $\mathrm{N}$ in plant tissue may contribute to a greater synthesis of low-molecular-weight compounds, such as glycine betaine 
and proline, which act as membrane osmoprotectants and macromolecules, and may aid in the osmotic adjustment of plants to salinity (Ashraf et al., 2018). On the other hand, K can minimize the effects of salinity by promoting the control of cell turgor, regulation of stomatal conductance, activation of enzymes, and translocation of carbohydrates in plants (Almeida et al., 2017; Hasanuzzaman et al., 2018).

Based on these hypotheses and on the need for utilization of saline water in the cultivation of fruit crops and fertilization management strategies to mitigate the negative effects of salinity, this study evaluated the effect of combinations of nitrogen and potassium doses on the physiology and fruit production of West Indian cherry irrigated with waters of different salinities, in the second year of cultivation.

\section{MATERIAL AND METHODS}

The experiment was carried out in the field using 60-L containers adapted as lysimeters, installed in an experimental area belonging to the Center of Sciences and Agri-food Technology of the Federal University of Campina Grande, in the municipality of Pombal, PB, Brazil. The reference geographic coordinates of the site are $6^{\circ} 48^{\prime} 16^{\prime \prime}$ South latitude, 37 $49^{\prime} 15^{\prime \prime}$ West longitude, and mean altitude of $144 \mathrm{~m}$. According to the Köppen-Geiger classification, adapted to Brazil, the climate of the region is classified as BSh, hot semi-arid, whose precipitation, mean temperature, and relative air humidity during the experimental period were $8.0 \mathrm{~mm}, 27.7^{\circ} \mathrm{C}$, and $44.8 \%$, respectively (Inmet, 2018).

The treatments were distributed in randomized blocks, with three replicates, in a $5 \times 4$ factorial scheme, corresponding to five salinity levels of irrigation water $(0.3 ; 1.3 ; 2.3 ; 3.3$ and $\left.4.3 \mathrm{dS} \mathrm{m}^{-1}\right)$ and four combinations of nitrogen and potassium doses $\left(\mathrm{C} 1=70 \% \mathrm{~N}+50 \% \mathrm{~K}_{2} \mathrm{O}\right.$; $\mathrm{C} 2=100 \% \mathrm{~N}+75 \% \mathrm{~K}_{2} \mathrm{O} ; \mathrm{C} 3=130 \% \mathrm{~N}+100 \% \mathrm{~K}_{2} \mathrm{O}$ and $\mathrm{C} 4=160 \% \mathrm{~N}+125 \% \mathrm{~K}_{2} \mathrm{O}$ of the dose recommended for West Indian Cherry for the second year), each plot consisting of one plastic container with one plant, totaling 60 experimental units.

The recommendation of fertilization for the West Indian cherry cultivar 'Flor Branca' under irrigated conditions, corresponding to $100 \mathrm{~g}$ of $\mathrm{N}$ and $80 \mathrm{~g}$ of $\mathrm{K}_{2} \mathrm{O}$ per plant per year, was adopted (Cavalcanti, 2008), equivalent to the doses of the treatments with 100\% nitrogen (N) and potassium $\left(\mathrm{K}_{2} \mathrm{O}\right)$, whose quantities applied in the first and second years, along with phosphate fertilization, are presented in Table 1 . The combinations of $\mathrm{N}$ and $\mathrm{K}_{2} \mathrm{O}$ doses began to be applied at 20 days after transplanting (DAT) as top-dressing via water of $0.3 \mathrm{dS} \mathrm{m}^{-1}$ electrical conductivity for all treatments, using urea $(45 \% \mathrm{~N})$ and potassium chloride $(60 \%$ $\mathrm{K}_{2} \mathrm{O}$ ) as sources, respectively.

Salinity levels were based on the study conducted by Sá et al. (2018a), who observed that irrigation using water with a salinity of up to $2.2 \mathrm{dS} \mathrm{m}^{-1}$ does not compromise the growth and physiology of the West Indian cherry cv. 'BRS 336 Jaburu'.

The saline waters of the treatments were prepared based on the relationship between $\mathrm{ECW}$ and salt concentration $\left(\mathrm{mmol}_{\mathrm{c}} \mathrm{L}^{-1}=\mathrm{EC} \times 10\right)$, through the addition of $\mathrm{NaCl}, \mathrm{CaCl}_{2} \cdot 2 \mathrm{H}_{2} \mathrm{O}$, and $\mathrm{MgCl}_{2} .6 \mathrm{H}_{2} \mathrm{O}$, maintaining the equivalent ratio of $7: 2: 1$, respectively, to the water of the lowest salinity $\left(0.3 \mathrm{dS} \mathrm{m}^{-1}\right)$ from the Coremas-Mãe d'Água reservoir system, which provides water for irrigation in the region. The application of saline waters (1.3 to $\left.4.3 \mathrm{dS} \mathrm{m}^{-1}\right)$ began at 41 DAT, with irrigations performed manually every day based on the principle of drainage lysimeter. A leaching fraction of $15 \%$ was applied every 15 days, and the leaching volume was calculated based on the volume of water applied within these 15 days.

Containers with dimensions of $0.58 \mathrm{~m}$ (height), $0.42 \mathrm{~m}$ (upper diameter), and $0.32 \mathrm{~m}$ (lower diameter) were spaced in the field with $1.8 \times 2.0 \mathrm{~m}$ between plants and between planting rows, respectively. These containers were supported on ceramic bricks, $20 \mathrm{~cm}$ height from the soil, at the base of which was a drainage system, composed of a drain with a diameter of $1 / 2$ inch 
(12.7 $\mathrm{mm})$ inserted at the end of the base and coupled to a 2-L PET bottle to collect drained water; a 3.0-cm-layer of crushed stone $\mathrm{n}^{\circ} 1$ and a $2.0-\mathrm{cm}$-thick layer of washed sand were placed at the bottom of the pot. Above the sand, $56 \mathrm{~L}$ of soil were placed, and the soil's physical and chemical attributes (Table 2) were determined in the Irrigation and Salinity Laboratory of the Center of Technology and Natural Resources (CTRN) of UFCG, using methodologies recommended by Donagema et al. (2011).

Table 1. Quantities of $\mathrm{N}$ and $\mathrm{K}_{2} \mathrm{O}$ applied per plant through the combinations of nitrogen and potassium fertilization and phosphate fertilization, performed in the first and second years of cultivation, up to 550 days after transplantation (DAT).

\begin{tabular}{cccc}
\hline & \multicolumn{3}{c}{ Quantities applied per plant } \\
\cline { 2 - 4 } Fertilization combinations & $\begin{array}{c}\text { 1st year } \\
\text { (up to 365 DAT) }\end{array}$ & $\begin{array}{c}\text { 2nd year } \\
(365-550 \mathrm{DAT})\end{array}$ & $\begin{array}{c}\text { Total } \\
\text { (up to 550 DAT) }\end{array}$ \\
\hline $\mathrm{C} 1-70 \% \mathrm{~N}+50 \% \mathrm{~K}_{2} \mathrm{O}$ & $70 \mathrm{~g} \mathrm{~N}+40 \mathrm{~g} \mathrm{~K}_{2} \mathrm{O}$ & $35 \mathrm{~g} \mathrm{~N}+20 \mathrm{~g} \mathrm{~K} \mathrm{O}_{2}$ & $105 \mathrm{~g} \mathrm{~N}+60 \mathrm{~g} \mathrm{~K} \mathrm{O}$ \\
$\mathrm{C} 2-100 \% \mathrm{~N}+75 \% \mathrm{~K}_{2} \mathrm{O}$ & $100 \mathrm{~g} \mathrm{~N}+60 \mathrm{~g} \mathrm{~K}_{2} \mathrm{O}$ & $50 \mathrm{~g} \mathrm{~N}+30 \mathrm{~g} \mathrm{~K}_{2} \mathrm{O}$ & $150 \mathrm{~g} \mathrm{~N}+90 \mathrm{~g} \mathrm{~K}_{2} \mathrm{O}$ \\
$\mathrm{C} 3-130 \% \mathrm{~N}+100 \% \mathrm{~K}_{2} \mathrm{O}$ & $130 \mathrm{~g} \mathrm{~N}+80 \mathrm{~g} \mathrm{~K}_{2} \mathrm{O}$ & $65 \mathrm{~g} \mathrm{~N}+40 \mathrm{~K}_{2} \mathrm{O}$ & $195 \mathrm{~g} \mathrm{~N}+120 \mathrm{~g} \mathrm{~K}_{2} \mathrm{O}$ \\
$\mathrm{C} 4-160 \% \mathrm{~N}+125 \% \mathrm{~K}_{2} \mathrm{O}$ & $160 \mathrm{~g} \mathrm{~N}+100 \mathrm{~g} \mathrm{~K}_{2} \mathrm{O}$ & $80 \mathrm{~g} \mathrm{~N}+50 \mathrm{~K}_{2} \mathrm{O}$ & $240 \mathrm{~g} \mathrm{~N}+150 \mathrm{~g} \mathrm{~K}_{2} \mathrm{O}$
\end{tabular}

Phosphate fertilization $\left(\mathrm{P}_{2} \mathrm{O}_{5}\right)$

\[ 20 \mathrm{~g} \]
\[ - \]
Note: The combinations of $\mathrm{N}$ and $\mathrm{K}_{2} \mathrm{O}$ doses were applied at an interval of 15 days. Phosphate
fertilization in the first year was performed with single superphosphate $\left(18 \% \mathrm{P}_{2} \mathrm{O}_{5}\right)$, by mixing the
fertilizer with the soil of the lysimeter, and in the second year, split into 12 applications of equal
portions, at an interval of 15 days, using monoammonium phosphate - $\mathrm{MAP}\left(61 \% \mathrm{P}_{2} \mathrm{O}_{5}\right.$ and $12 \%$
$\mathrm{N})$; the quantity of $\mathrm{N}$ supplied was subtracted from the doses of treatments with nitrogen
fertilization.

The seedlings came from a commercial nursery accredited in the National Registry of Seeds and Seedlings, located in the District of São Gonçalo, Sousa - PB, grafted by the full cleft method, using rootstock and scion of the cultivars 'Junco' and 'Flor Branca', respectively. Transplanting to the containers was performed when the seedlings reached $30 \mathrm{~cm}$ in height, at 120 days after grafting. After transplanting, a 4.0-cm-thick layer of mulch, composed of grass residues, was maintained to minimize water losses by evaporation.

The effects of treatments on plant physiology were analyzed at 540 DAT, through water potential in the branch $(\Psi \mathrm{w})$, relative water content (RWC), water saturation deficit (WSD) and intercellular electrolyte leakage (EL) in the leaf blade, chlorophyll contents in leaves (CHLtotal), stomatal conductance (gs), and $\mathrm{CO}_{2}$ assimilation rate (A). 
Table 2. Physical and chemical attributes of the 0-0.20 m soil layer (Neossolo Flúvico Eutrófico - Entisol) used in the experiment, before application of the treatments, collected in Lot 14, Sector I, of the Irrigated Perimeter of Várzeas de Sousa-PB, Brazil.

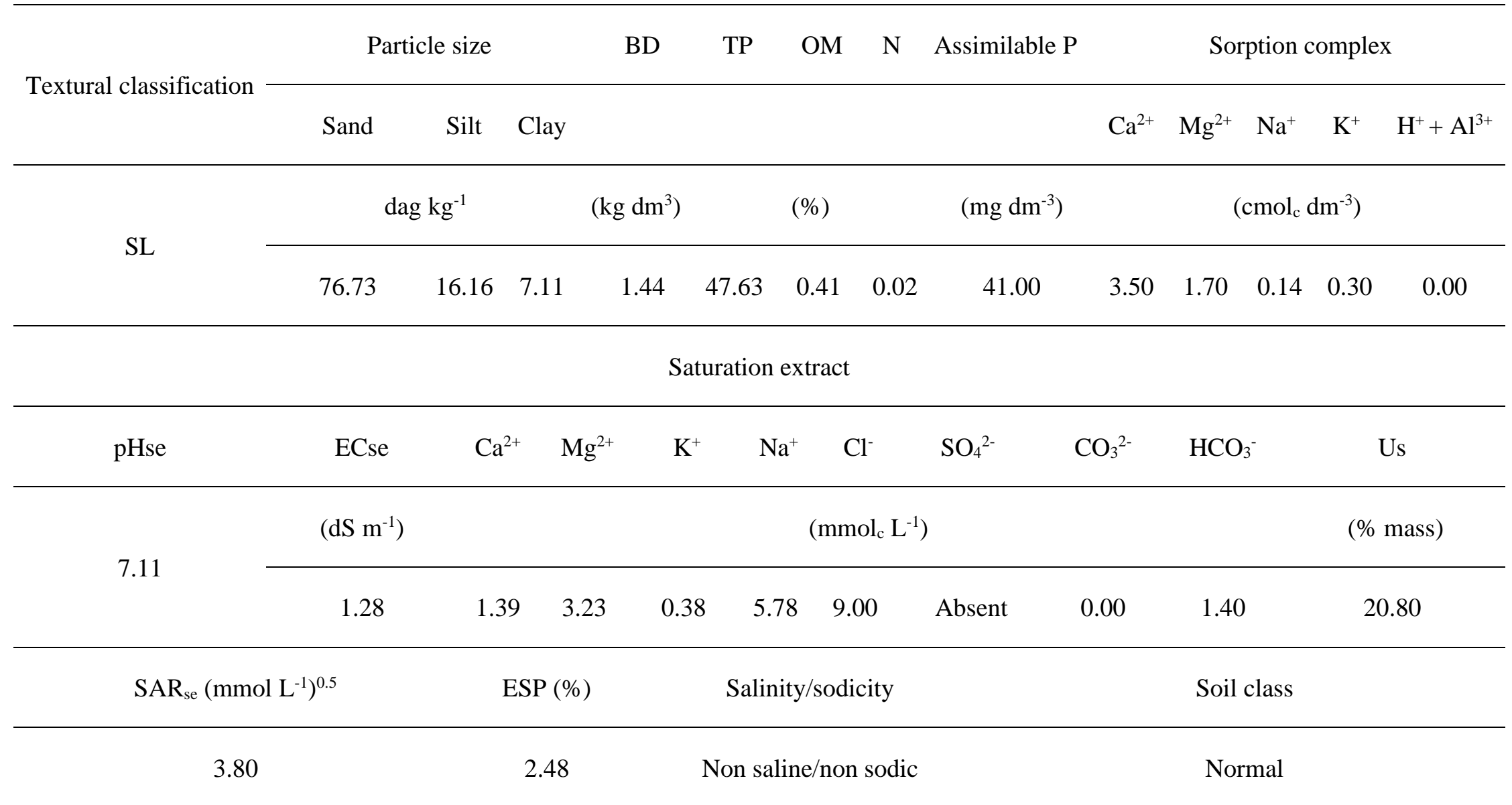

SL - Sandy loam; BD - Bulk density; TP - Total porosity; OM - Organic matter determined by Walkley-Black wet digestion; $\mathrm{pHse}$ - $\mathrm{pH}$ of saturation extract, ECse - electrical conductivity of saturation extract at $25^{\circ} \mathrm{C}$; Us - soil saturation moisture; SAR $\mathrm{Se}_{\mathrm{se}}$ - Sodium adsorption ratio of saturation extract; ESP - exchangeable sodium percentage; $\mathrm{P}, \mathrm{K}^{+}$and $\mathrm{Na}^{+}$extracted with Mehlich-1 extractant; $\mathrm{Ca}^{2+}$ and $\mathrm{Mg}^{2+}$ extracted with 1.0 $\mathrm{M} \mathrm{KCl}$ at $\mathrm{pH} 7.0 ; \mathrm{H}^{+}+\mathrm{Al}^{3+}$ extracted by $0.5 \mathrm{M} \mathrm{CaOAc}$ at $\mathrm{pH}$ 7.0. 
The $\Psi_{\mathrm{W}}$ was analyzed in a pressure chamber (Scholander et al., 1965), in the terminal part of the branch removed with an approximate length of $15 \mathrm{~cm}$ and detached from the plant where the diameter reached $1.9 \mathrm{~mm}$, in the median region of the crown at 6:30 a.m. RWC and WSD were determined in 4 fully expanded leaves, taken from the intermediate third of branches located in the same region of the crown where the branches were collected for the $\Psi_{\mathrm{w}}$ evaluation, adopting methodologies of Weatherley (1950) and Taiz et al. (2017), respectively.

Electrolyte leakage in the cell membrane was determined according to Bajji et al. (2002), in eight leaf discs collected from four leaves located in the middle third of the branch, in the median region of the crown. Total chlorophyll content was determined by the sum of chlorophyll a and chlorophyll $b$ contents, analyzed in 6 discs of plant tissue taken from the middle third of the fourth pair of leaves of a branch located in the median region of the crown, corresponding to a total disc area of $3.18 \mathrm{~cm}^{2}$, using the methodology of Lichtenthäler (1987). The data were obtained in $\mathrm{mg} \mathrm{L}^{-1}$ and, based on the leaf disc area $\left(3.18 \mathrm{~cm}^{2}\right)$ and dilution of the extract in $80 \%$ acetone $(6 \mathrm{~mL})$, were transformed into units of mass per $\mathrm{m}^{2}\left(\mathrm{~g} \mathrm{~m}^{-2}\right.$ fresh weight).

Stomatal conductance and $\mathrm{CO}_{2}$ assimilation rate were analyzed between 6:00 and 9:00 a.m., in the same region of the plant in which the other physiological variables mentioned above were analyzed, using a portable infrared carbon dioxide analyzer (IRGA), LCPro+ Portable Photosynthesis System ${ }^{\circledR}$ model (ADC BioScientific Limited, UK), operating at room temperature, irradiation of $1200 \mu \mathrm{mol}$ photons $\mathrm{m}^{-2} \mathrm{~s}^{-1}$ and airflow of $200 \mathrm{~mL} \mathrm{~min} \mathrm{~m}^{-1}$, and atmospheric $\mathrm{CO}_{2}$ concentration.

Fruit formation variables were analyzed in ripe harvested fruits with intense red peel, at harvests performed between 420 and 550 DAT, through the equatorial (ED) and polar diameter (PD), average fruit size (AFS) and average fruit mass (AFM). The measurements were taken in a representative sample of 15 fruits per plant, randomly selected from the total fruits collected. PD was measured in the direction from the base to the apex of the fruit, and ED in the median region in the direction of width, using a digital caliper. AFS was obtained by means of PD and ED. AFM was determined by dividing the total weight of fruits, weighed on a precision scale $(0.01 \mathrm{~g})$, by the number of fruits harvested.

The data were subjected to analysis of variance by the F test at 0.01 and 0.05 probability levels; the means of salinity levels were analyzed by regression and the means of combinations of nitrogen and potassium fertilization were compared by Tukey test at 0.05 probability level, using the statistical program SISVAR, Version 5.6 for data processing (Ferreira, 2014).

\section{RESULTS AND DISCUSSION}

The interaction between irrigation water salinity and the combination of NK doses was not significant $(\mathrm{p}>0.05)$ for the physiological and fruit production of West Indian cherry in the second year of cultivation (Table 3 ). However, there was a significant single effect $(p<0.05)$ of water salinity on the water potential in the branch, water saturation deficit, relative water content in the leaf, electrolyte leakage in the leaf blade, total chlorophyll, $\mathrm{CO}_{2}$ assimilation rate, equatorial and polar diameters of the fruits, as well as their average size and average mass. These variables were also significantly influenced by the combination of NK doses, except for the water saturation deficit and relative water content, whereas stomatal conductance was not affected by any of the factors.

Despite reports of the positive influence of $\mathrm{N}$ and $\mathrm{K}$ on the mitigation of salt stress in plants (Andrade Junior et al., 2011; Ashraf et al., 2018; Hasanuzzaman et al., 2018), the noninteractive effect between the factors (Table 3) shows that the combinations of $\mathrm{N}$ and $\mathrm{K}$ doses were not efficient in reducing the nutritional imbalance caused by toxic ions $\mathrm{Na}^{+}$and $\mathrm{Cl}^{-}$, thus not mitigating salt stress on the physiological traits and fruit production, as can be seen further on in this study. Sá et al. (2018b) also observed that there was no significant effect of the interaction between levels of irrigation water salinity and combinations of nitrogen and

Rev. Ambient. Água vol. 16 n. 6, e2780 - Taubaté 2021 
phosphate fertilization on the relative water content, water saturation deficit, percentage of electrolyte leakage, longitudinal and transverse diameters of fruits and average fruit mass, in West Indian cherry in the first year of cultivation.

Table 3. Summary of the analysis of variance for water potential in the branch $\left(\Psi_{w}\right)$, relative water content (RWC), water saturation deficit in the leaf (WSD), electrolyte leakage in the leaf blade (EL), total chlorophyll content in the leaf (CHLtotal), stomatal conductance (gs) and $\mathrm{CO}_{2}$ assimilation rate (A) at 540 days after transplanting and, polar diameter (PD), equatorial diameter (ED), average fruit size (AFS) and average fruit mass (AFM) obtained from harvests performed between 420 and 550 days after transplanting, in West Indian cherry irrigated with waters of different salinities, under combinations of nitrogen and potassium fertilization.

\begin{tabular}{|c|c|c|c|c|c|c|c|c|}
\hline \multirow{2}{*}{ Source of variation } & \multirow[b]{2}{*}{$\mathrm{DF}$} & \multicolumn{7}{|c|}{ Mean squares } \\
\hline & & $\Psi_{\mathrm{w}}$ & RWC & \multicolumn{2}{|c|}{ WSD } & EL & CHLtotal & gs \\
\hline Salinity (S) & 4 & $0.149 * * \quad 9$ & $97.24 * *$ & \multicolumn{2}{|c|}{$97.24 * *$} & $396.59 * *$ & $0.0116^{* *}$ & $0.00024^{\mathrm{ns}}$ \\
\hline NK combination (C) & 3 & $0.171 * *$ & $2.77^{\mathrm{ns}}$ & \multicolumn{2}{|c|}{$2.77^{\mathrm{ns}}$} & $97.88 * *$ & $0.0101 * *$ & $0.00006^{\mathrm{ns}}$ \\
\hline $\mathrm{S} * \mathrm{C}$ Interaction & 12 & $0.034^{\mathrm{ns}}$ & $15.55^{\mathrm{ns}}$ & \multicolumn{2}{|c|}{$15.55^{\mathrm{ns}}$} & $8.22^{\mathrm{ns}}$ & $0.0013^{\mathrm{ns}}$ & $0.00015^{\mathrm{ns}}$ \\
\hline Block & 2 & $0.034^{\mathrm{ns}} \quad 9$ & $95.17 * *$ & \multicolumn{2}{|c|}{$95.17 * *$} & $40.52^{\mathrm{ns}}$ & $0.0007^{\mathrm{ns}}$ & $0.00408 * *$ \\
\hline Error & 38 & 0.024 & 16.66 & \multicolumn{2}{|c|}{16.66} & 17.90 & 0.0016 & 0.00027 \\
\hline $\mathrm{CV}(\%)$ & - & 6.22 & 5.31 & \multicolumn{2}{|c|}{17.60} & 21.62 & 23.28 & 42.48 \\
\hline Source of variation & $\mathrm{DF}$ & A & \multicolumn{2}{|c|}{$\mathrm{PD}$} & \multicolumn{2}{|c|}{$\mathrm{ED}$} & AFS & AFM \\
\hline Salinity (S) & 4 & $9.49 *$ & \multicolumn{2}{|c|}{$8.099 * *$} & \multicolumn{2}{|c|}{$10.515^{* *}$} & $8.552 * *$ & $0.928 * *$ \\
\hline NK combination (C) & 3 & $16.88^{* *}$ & \multicolumn{2}{|c|}{$3.406^{* *}$} & \multicolumn{2}{|c|}{$4.601 * *$} & $3.896^{* *}$ & $0.440 * *$ \\
\hline $\mathrm{S} * \mathrm{C}$ Interaction & 12 & $4.21^{\mathrm{ns}}$ & \multicolumn{2}{|c|}{$0.475^{\mathrm{ns}}$} & \multicolumn{2}{|c|}{$0.788^{\mathrm{ns}}$} & $0.596^{\mathrm{ns}}$ & $0.117^{\mathrm{ns}}$ \\
\hline Block & 2 & $27.82 * *$ & \multicolumn{2}{|c|}{$1.538^{\mathrm{ns}}$} & \multicolumn{2}{|c|}{$2.776^{*}$} & $1.959^{*}$ & $0.276^{*}$ \\
\hline Error & 38 & 3.05 & \multicolumn{2}{|c|}{0.3009} & \multicolumn{2}{|c|}{0.5522} & 0.4992 & 0.0839 \\
\hline $\mathrm{CV}(\%)$ & - & 36.85 & \multicolumn{2}{|c|}{3.87} & \multicolumn{2}{|c|}{4.61} & 4.65 & 12.70 \\
\hline
\end{tabular}

$*$ and ${ }^{* *}$, respectively significant at $\mathrm{p}<0.05$ and $\mathrm{p}<0.01$; ns - not significant; DF - degrees of freedom; CV

- coefficient of variation.

It can be observed (Figure 1A) that the increase in irrigation water salinity reduced the water potential in the branch of West Indian cherry plants by $2.58 \%$ per unit increase in ECw. It must be pointed out that this phenomenon results from the accumulation of organic solutes in the cytosol and ions in the vacuole of cells in response to salt stress to carry out the osmotic adjustment; with this occurring the decrease of the internal water potential in the tissue of the branches (Silva et al., 2016; Sá et al., 2019). 

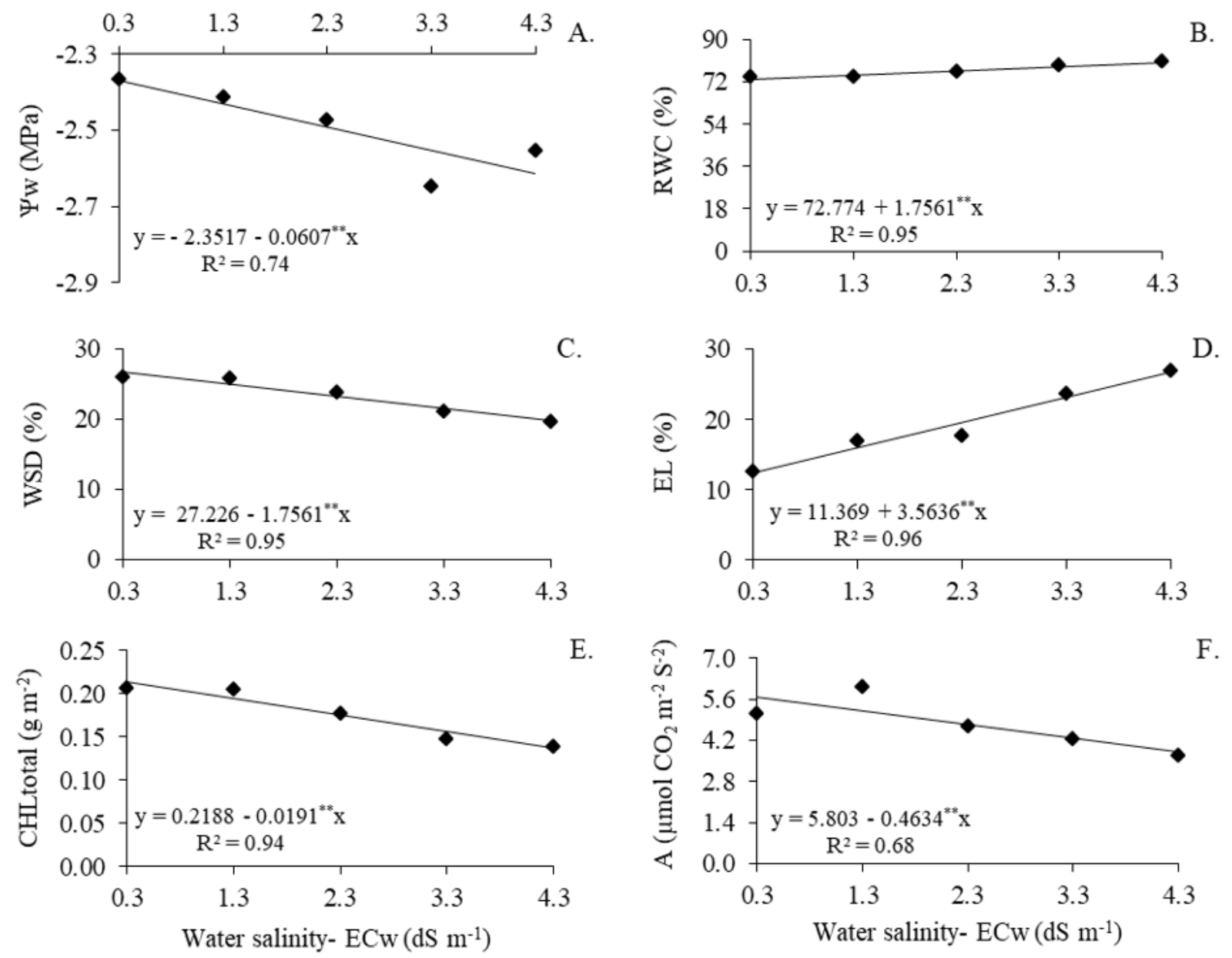

Figure 1. Water potential in the branch - $\Psi_{\mathrm{W}}(\mathrm{A})$, relative water content - RWC (B), water saturation deficit - WSD (C) and electrolyte leakage in the leaf blade - EL (D), total chlorophyll content in the leaf - CHLtotal (E), and $\mathrm{CO}_{2}$ assimilation rate $(\mathrm{F})$, in West Indian cherry irrigated with waters of different salinities at 540 days after transplantation.

The relative water content in the leaf increased with a linear increase of $2.41 \%$ per unit of $\mathrm{ECw}$ (Figure 1B), which resulted in a decrease in the water saturation deficit in the leaf by $6.45 \%$ per unit increment in ECw (Figure 1C). These effects are probably related to osmotic adjustment, due to the accumulation of organic solutes in the cytosol and ions in the vacuole of cells, which contributed to increased water absorption by these tissues through an osmotic gradient, resulting in greater turgescence in the leaves; this was also proven in the present study by the non-significant effect of water salinity on stomatal conductance (Table 3), probably due to the maintenance of turgor of stomatal guard cells. The increase in the water content in the leaves with increasing salinity in irrigation water was also observed in cashew plants by Carneiro et al. (2002), who associated this phenomenon with the effect of osmotic adjustment, by the accumulation of ions in the vacuole of cells and the synthesis of organic compounds.

Figure 1D shows that the increase in irrigation water salinity linearly intensified electrolyte leakage in leaf blade cells, resulting in a $31.35 \%$ per unit increase in water salinity level. The increase in the extrusion of electrolytes is associated with the toxic effects of $\mathrm{Na}^{+}$and $\mathrm{Cl}^{-}$ions accumulated in the leaves, which promote structural changes in cell membranes, with consequent rupture (Ferraz et al., 2015), and with the increase of reactive oxygen species, which cause lipid peroxidation and oxidation of the cell membranes and organelles, resulting in degradation and, consequently, loss of internal content of the cells (Mendes et al., 2011).

Figures $1 \mathrm{E}$ and $1 \mathrm{~F}$ show that the total chlorophyll content in the leaves and the $\mathrm{CO}_{2}$ assimilation rate were reduced by the increase in salt stress caused by irrigation water, with 
linear reductions, respectively, of 8.73 and $7.98 \%$ per unit increase in $\mathrm{ECw}$. The decrease in chlorophyll content in leaves is associated with the degradation of chloroplasts due to the rupture of their membranes (Sousa et al., 2017) and with the increase in the activity of the chlorophyll enzyme, which degrades the molecules of these photosynthesizing pigments under conditions of salt stress (Sá et al., 2019a).

For the $\mathrm{CO}_{2}$ assimilation rate, the decrease may have resulted from the degradation of chlorophyll molecules, which reduces the photochemical efficiency in Photosystem II, resulting in the low formation of the NADPH reducer and ATP. These substances are used as an energy source for $\mathrm{CO}_{2}$ assimilation, and decrease the efficiency of carboxylation of the RuBisCO enzyme responsible for carbon fixation for photosynthesis (Taiz et al., 2017); this is generally affected by the increase of $\mathrm{Cl}^{-}$in the leaves (Silva et al., 2016), a phenomenon already reported in West Indian cherry crops subjected to salt stress (Alvarenga et al., 2019; Lima et al., 2019a; Sá et al., 2019).

It can be observed (Figure 2A) that the water potential in the branch of plants under the fertilization combinations $\mathrm{C} 1, \mathrm{C} 2$ and $\mathrm{C} 3$ did not differ statistically, while fertilization with the combination $\mathrm{C} 4$ resulted in a lower value of this variable. The application of high doses of $\mathrm{N}$ and $\mathrm{K}(160 / 125 \%)$ through $\mathrm{C} 4$ may have resulted in nutritional imbalance and excessive accumulation of $\mathrm{NO}_{3}{ }^{-}$and $\mathrm{K}^{+}$in the cellular vacuole of leaves and branches, causing an osmotic gradient (Ashraf et al., 2018; Hasanuzzaman et al., 2018), resulting in the reduction of free energy of water, leading to reduction in the internal water potential of the branch.

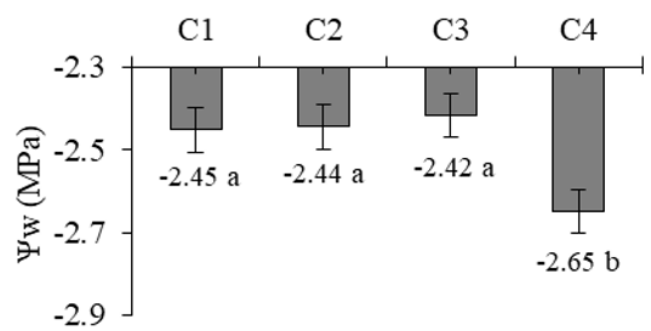

A.

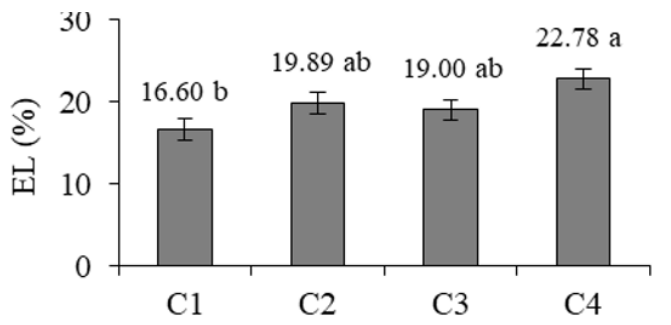

B.

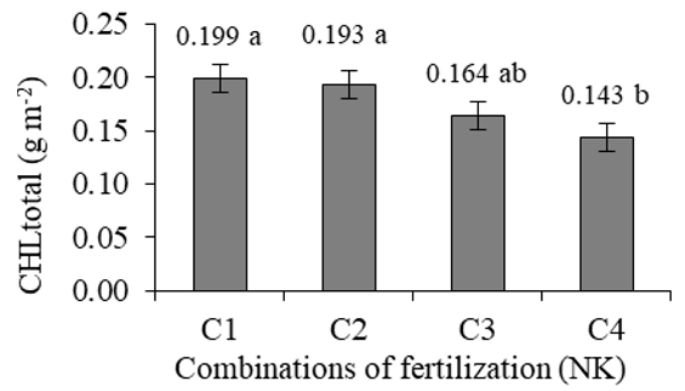

C.

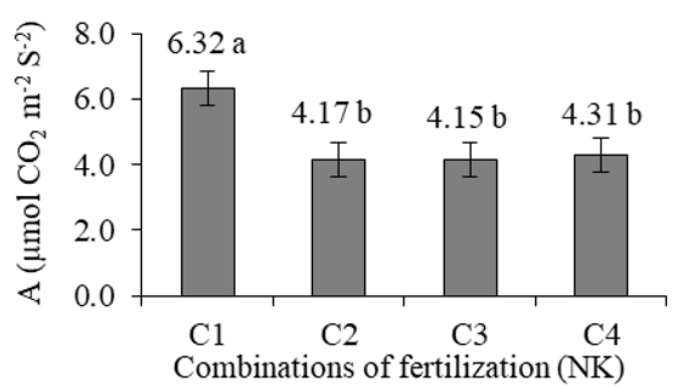

$\mathrm{C} 1-70 \% \mathrm{~N}+50 \% \mathrm{~K}_{2} \mathrm{O} ; \mathrm{C} 2-100 \% \mathrm{~N}+75 \% \mathrm{~K}_{2} \mathrm{O} ; \mathrm{C} 3-130 \% \mathrm{~N}+100 \% \mathrm{~K}_{2} \mathrm{O}$ and $\mathrm{C} 4-160 \% \mathrm{~N}+125 \% \mathrm{~K}_{2} \mathrm{O}$; means followed by different letters indicate significant difference between treatments by Tukey test $(\mathrm{p}<0.05)$. Vertical bars represent the standard error of the mean $(n=3)$.

Figure 2. Water potential in the branch - $\Psi_{\mathrm{w}}(\mathrm{A})$, electrolyte leakage in the leaf blade - EL (B), total chlorophyll - CHLtotal (C), and $\mathrm{CO}_{2}$ assimilation rate - A (D) in West Indian cherry leaves, as a function of different combinations of nitrogen and potassium fertilization at 540 days after transplantation.

Figure $2 \mathrm{~B}$ shows that the percentage of electrolyte leakage in the leaf blade was lower in plants fertilized with the combination $\mathrm{C} 1$, while the total chlorophyll content and the $\mathrm{CO}_{2}$ assimilation rate obtained higher values with the use of this fertilization combination (Figures 2C and 2D). On the other hand, the increase in NK doses intensified electrolyte leakage and reduced the total chlorophyll content and the $\mathrm{CO}_{2}$ assimilation rate, mainly under the use of the C4 fertilization combination. 
The $\mathrm{C} 1$ combination may have promoted greater nutritional balance, resulting in lower electrolyte extrusion and higher chlorophyll content and $\mathrm{CO}_{2}$ assimilation rate in plants due to the application of adequate doses of nitrogen and potassium, given that $\mathrm{N}$ is an integral component of proteins that make up cell membranes, improving their permeability and selectivity (Ashraf et al., 2018), besides being one of the main constituents of chlorophyll molecules (Taiz et al., 2017). In addition, $\mathrm{K}$ can decrease the formation of reactive oxygen species, ensuring greater integrity of cell membranes and chloroplasts, with positive contributions to cationic balance and osmoregulation (Almeida et al., 2017; Hasanuzzaman et $a l ., 2018$ ), besides stimulating the activity of RuBisCO, which contributes to an increase in $\mathrm{CO}_{2}$ assimilation rate (Taiz et al., 2017).

On the other hand, it is emphasized that the high doses of NK applied through $\mathrm{C} 4$ may have caused increased oxidative stress, leading to greater damage to cell membranes and chlorophyll molecules; this phenomenon may occur mainly with increased doses of nitrogen, which provides excess ammonium, where plants have greater sensitivity (Kováčik et al., 2020). The decrease in $\mathrm{CO}_{2}$ assimilation rate in the $\mathrm{C} 2, \mathrm{C} 3$, and $\mathrm{C} 4$ combinations is also related to an excessive amount of $\mathrm{N}$, which may have promoted increased oxygenase activity of the RuBisCO enzyme to the detriment of carboxylase, and $\mathrm{K}$ causing decreased activity of the $\mathrm{CO}_{2-}$ fixing enzyme (RuBisCO) (Melo et al., 2009).

Regarding fruit characteristics, it can be observed (Figures 3A, 3B, 3C, and 3D) that the increase in the salinity level of irrigation water negatively affected the equatorial and polar diameters, average size and average mass of the fruits, causing decreases with per unit increment in ECw of 3.12, 2.99, 2.50, and 5.21\% in these variables, respectively. This is due to the higher energy cost to perform osmotic adjustment with increased salinity, through the synthesis of organic solutes and diversion of these substrates that would be transferred and accumulated in the fruits in the form of starch, proteins and cell wall (Taiz et al., 2017).

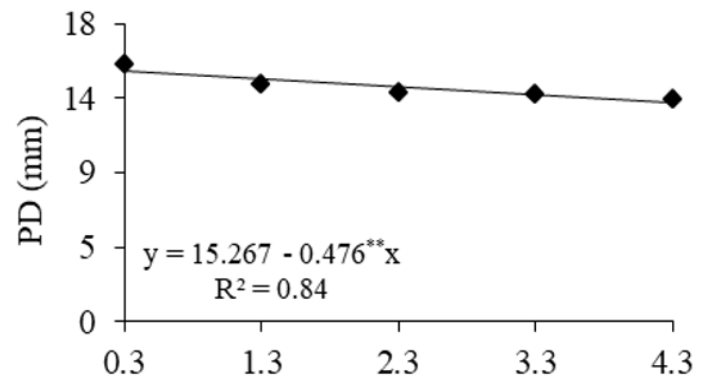

A.
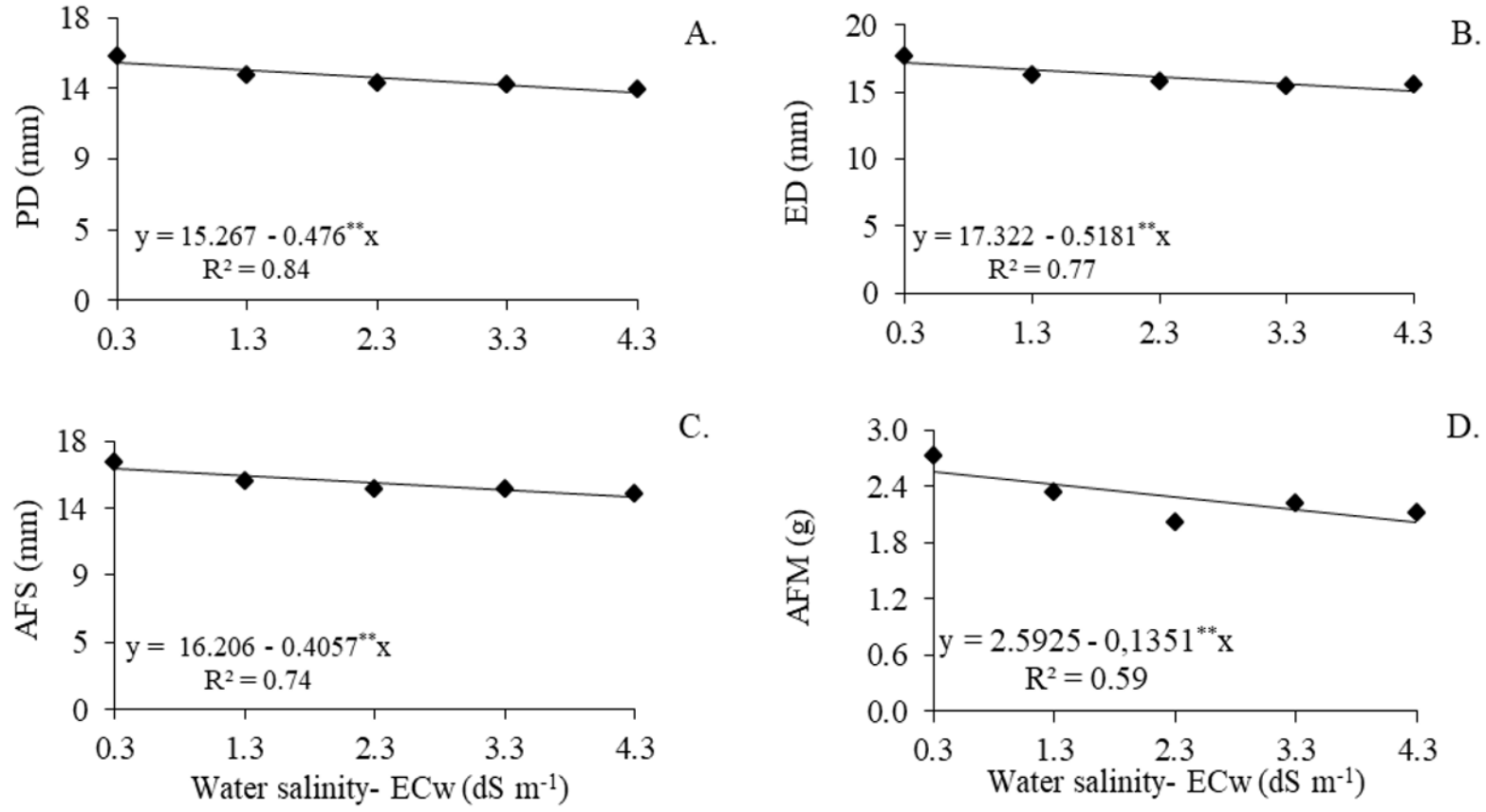

C.

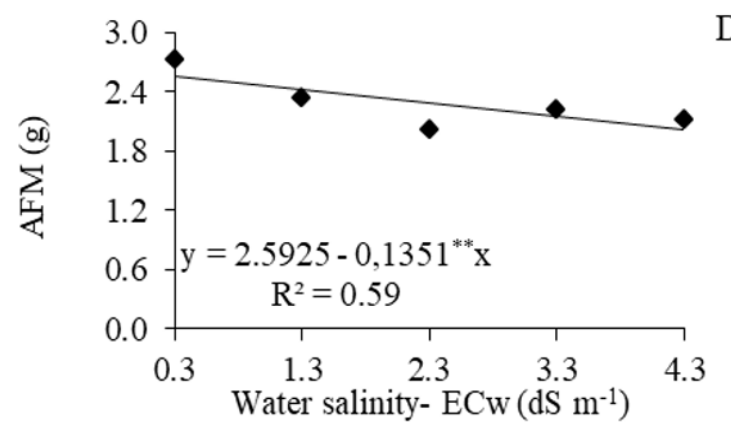

Figure 3. Polar diameter - PD (A), equatorial diameter - ED (B), average fruit size - AFS (C), and average fruit mass - AFM (D) of West Indian cherry, as a function of irrigation water salinity - ECw, of fruit harvests carried out between 420 and 550 days after transplanting.

This phenomenon is also associated with a decrease in $\mathrm{CO}_{2}$ assimilation rate, which reduced the synthesis of assimilates that would be transferred and accumulated in fruits, and with physiological disturbances caused by increased formation of reactive oxygen species, 
which damage cell membranes, chlorophylls, proteins, lipids and nucleic acids (Mendes et al., 2011; Sousa et al., 2017; Ashraf et al., 2018). Similarly, Sá et al. (2019) observed a decrease in the longitudinal diameter and mass of fruits of 'BRS Jaburu' irrigated by water with salinity ranging from 0.6 to $3.8 \mathrm{dS} \mathrm{m}^{-1}$ at 365 days after transplanting. Also, Lima et al. (2019b) found a reduction in the average fruit mass of this cultivar caused by irrigation with $\mathrm{ECw}$ from $3.8 \mathrm{dS}$ $\mathrm{m}^{-1}$ at 515 days after transplanting.

By analyzing the effect of fertilization combinations on West Indian cherry fruits, it was observed (Figures 4A, 4B, 4C, and 4D) that the largest polar diameter, equatorial diameter, average size, and average mass of fruits were obtained in plants fertilized with the combination $\mathrm{C} 1$, followed by the combination $\mathrm{C} 2$. This effect may be related to the positive influence of the adequate doses of $\mathrm{N}$ and $\mathrm{K}$ supplied through these combinations on physiological and biochemical processes. These phenomena were proven in the present study by fertilization with the combination $\mathrm{C}$ 1, in which the plants showed lower electrolyte leakage, higher concentration of total chlorophyll in leaves, and a higher $\mathrm{CO}_{2}$ assimilation rate (Figures 2B, 2C, and 2D).
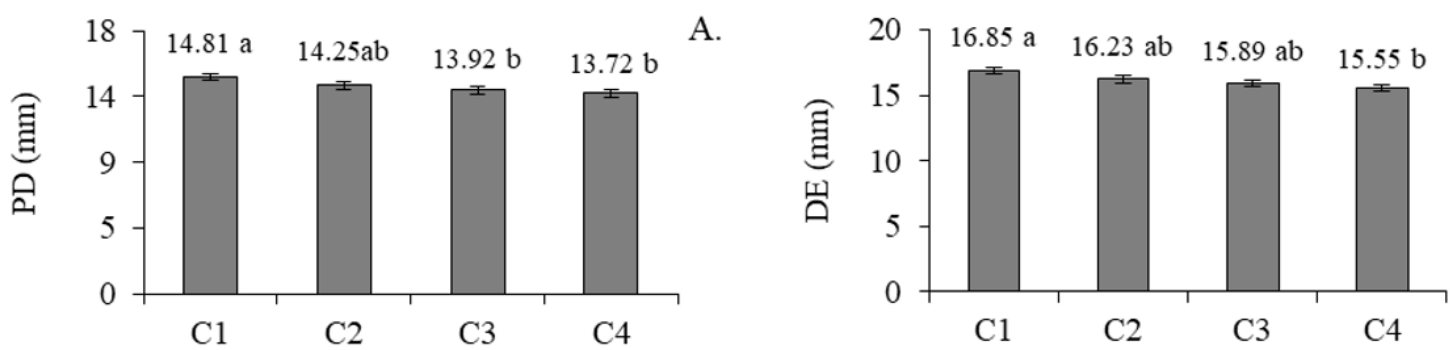

B.

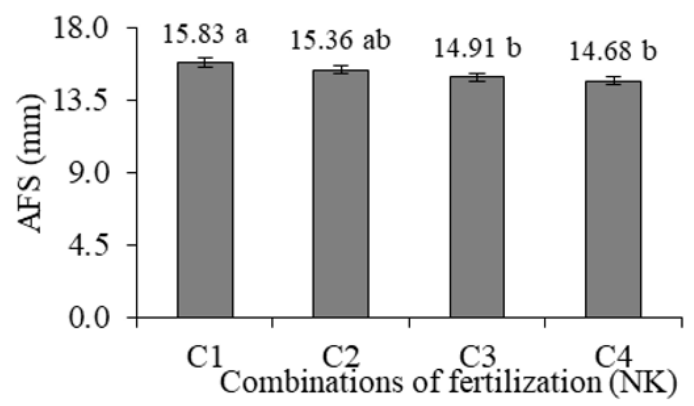

C.

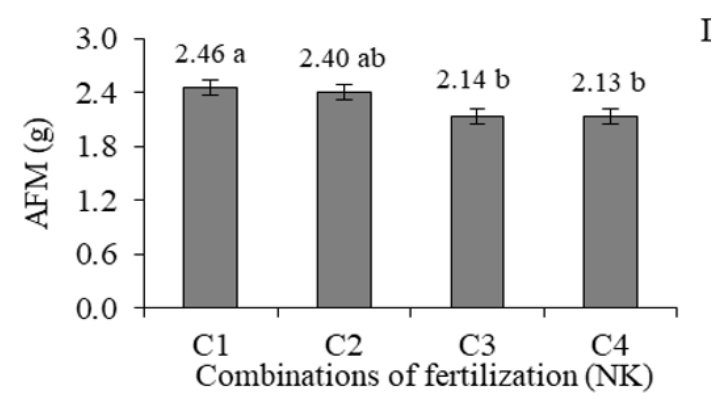

$\mathrm{C} 1-70 \% \mathrm{~N}+50 \% \mathrm{~K}_{2} \mathrm{O} ; \mathrm{C} 2-100 \% \mathrm{~N}+75 \% \mathrm{~K}_{2} \mathrm{O} ; \mathrm{C} 3-130 \% \mathrm{~N}+100 \% \mathrm{~K}_{2} \mathrm{O}$ and $\mathrm{C} 4-160 \% \mathrm{~N}+125 \% \mathrm{~K}_{2} \mathrm{O}$; means followed by different letters indicate significant difference between treatments by Tukey test $(\mathrm{p}<0.05)$. Vertical bars represent the standard error of the mean $(n=3)$.

Figure 4. Polar diameter - PD (A) and equatorial - ED (B), average fruit size - AFS (C), and average fruit mass - AFM (D) of West Indian cherry, as a function of different combinations of nitrogen and potassium fertilization, in fruit harvests performed between 420 and 550 days after transplanting.

Regarding the lower values observed, mainly under the fertilization combination $\mathrm{C} 4$ $\left(160 \% \mathrm{~N}+125 \% \mathrm{~K}_{2} \mathrm{O}\right)$, it is possible to affirm that, in addition to nutritional imbalance and oxidative stress, these doses increased salinity in the soil solution as a result of the increase in the amount of nitrogen and potassium fertilizers applied, harmed the physiological activities and fruit formation of West Indian cherry plants, since urea and potassium chloride used as a source of $\mathrm{N}$ and $\mathrm{K}$ have high salt indices, corresponding to 75 and $115 \%$, respectively (Borges and Silva, 2011).

\section{CONCLUSIONS}

1. The different combinations of nitrogen and potassium doses did not mitigate the harmful effects of salt stress on plant physiology and fruit production but impaired these variables with 
doses from $100 \% \mathrm{~N}+75 \% \mathrm{~K}_{2} \mathrm{O}$.

2. Irrigation using water with salinity above $0.3 \mathrm{dS} \mathrm{m}^{-1}$ intensifies intercellular electrolyte leakage (EL), reduces water potential in plants, total chlorophyll content in leaves, and $\mathrm{CO}_{2}$ assimilation rate, reducing the diameter and mass of West Indian cherry fruits in the second year of cultivation.

3. Plants fertilized with $70 \% \mathrm{~N}+50 \% \mathrm{~K}_{2} \mathrm{O}$ of the recommended dose have lower EL, higher $\mathrm{CO}_{2}$ assimilation rate, higher chlorophyll content in leaves, and produce fruits with larger diameter and mass, regardless of the salinity of the irrigation water.

\section{ACKNOWLEDGEMENTS}

To the Universidade Federal de Campina Grande - UFCG for the use of infrastructure and to the Coordenação de Aperfeiçoamento de Pessoal de Nível Superior (CAPES) for the research fellowship.

\section{REFERENCES}

ALMEIDA, D. M.; OLIVEIRA, M. M.; SAIBO, N. J. M. Regulation of $\mathrm{Na}^{+}$and $\mathrm{K}^{+}$homeostasis in plants: Towards improved salt stress tolerance in crop plants. Genetics and Molecular Biology, v. 40, n. 1, p. 326-345, 2017. https://doi.org/10.1590/1678-4685-GMB-20160106

ALVARENGA, C. F. S.; SILVA, E. M. da; NOBRE, R. G.; GHEYI, H. R.; LIMA, G. S. de; SILVA, L. de À. Morfofisiologia de aceroleira irrigada com águas salinas sob combinações de doses de nitrogênio e potássio. Revista de Ciências Agrárias, v. 42, n. 1, p. 194-205, 2019. https://doi.org/10.19084/RCA18215

ANDRADE JÚNIOR, W. P.; PEREIRA, F. H. F.; FERNANDES, O. B.; QUEIROGA, R. C. F.; QUEIROGA, F. M. de. Efeito do nitrato de potássio na redução do estresse salino no meloeiro. Revista Caatinga, v. 24, n. 3, p. 110-119, 2011.

ASHRAF, M.; SHAHZAD, S. M.; IMTIAZ, M.; RIZWAN, M. S.; ARIF, M. S.; KAUSAR, R. Nitrogen nutrition and adaptation of glycophytes to saline environment: a review. Archives of Agronomy and Soil Science, v. 64, n. 9, p. 1181-1206, 2018. https://doi.org/10.1080/03650340.2017.1419571

BAJJI, M.; KINET, J. M.; LUTTS, S. The use of the electrolyte leakage method for assessing cell membrane stability as a water stress tolerance test in durum wheat. Plant Growth Regulation, v. 36, n. 1, p. 61-70, 2002.

BORGES, A. L.; SILVA, D. J. Fertilizantes para fertirrigação. In: SOUSA, V. F. de; MAROUElli, W. A.; COELHO, E. F.; PINTO, J. M.; COELHO FILHO, M. A. (ed.). Irrigação e fertirrigação em fruteiras e hortaliças. Brasília: Embrapa Informação Tecnológica, 2011. p.253-264.

CARNEIRO, P. T.; FERNANDES, P. D.; GHEYI, H. R.; SOARES, F. A .L. Germinação e crescimento inicial de genótipos de cajueiro anão-precoce em condições de salinidade. Revista Brasileira de Engenharia Agrícola e Ambiental, v. 6, n. 2, p. 199-206, 2002.

CAVAlCANTI, F. J. A. Recomendações de adubação para o Estado de Pernambuco: 2. aproximação. 3. ed. Recife: IPA, 2008. 212 p. 
DONAGEMA, G. K.; CAMPOS, D. V. B. de; CALDERANO, S. B.; TEIXEIRA, W. G.; VIANA, J. H. M. Manual de métodos de análise de solo. Rio de Janeiro: Embrapa Solos, 2011.230p.

ESASHIKA, T.; OLIVEIRA, L. A. de; MOREIRA, F. W. Resposta da aceroleira a adubação orgânica, química e foliar num Latossolo da Amazônia Central. Revista de Ciências Agrárias, v. 36, n. 4, p. 399-410, 2013. https://doi.org/10.19084/rca.16325

FERRAZ, R. L. S.; MAGALHÃES, I. D.; BELTRÃO, N. E. de M.; MELO, A. S. de; BRITO NETO, J. F. de; ROCHA, M. do S. Photosynthetic pigments, cell extrusion and relative leaf water content of the castor bean under silicon and salinity. Revista Brasileira de Engenharia Agrícola e Ambiental, v. 19, n. 9, p. 841-848, 2015. http://dx.doi.org/10.1590/1807-1929/agriambi.v19n9p841-848

FERREIRA, D. F. Sisvar: a guide for its bootstrap procedures in multiple comparisons. Ciência e Agrotecnologia, v. 38, n. 2, p. 109-112, 2014. http://dx.doi.org/:10.1590/S141370542014000200001

FLOWERS, T. J.; MUNNS, R.; COLMER, T. D. Sodium chloride toxicity and the cellular basis of salt tolerance in halophytes. Annals of Botany, v. 115, n. 3, p. 419-431, 2014. http://dx.doi.org/10.1093/aob/mcu217

HASANUZZAMAN, M.; BHUYAN, M. H. M. B.; NAHAR, K.; HOSSAIN, M. S.; MAHMUD, J. A.; HOSSEN, M. S. Potassium: a vital regulator of plant responses and tolerance to abiotic stresses. Agronomy, v. 8, n. 3; p. 1-29, 2018. https://doi.org/10.3390/agronomy8030031

INMET. Estações dados. Available at: http://www.inmet.gov.br/portal/index.php?r=estacoes/estacoesAutomaticas Access: 30 Oct. 2018.

IBGE. Produção e área nos estabelecimentos agropecuários com mais de 50 pés existentes. Rio de Janeiro: IBGE, 2017.

KOVÁČIK, J.; DRESLER, S.; PETERKOVÁ, V.; BABULA, P. Nitrogen nutrition modulates oxidative stress and metabolite production in Hypericum perforatum. Protoplasma, v. 257, n. 1, p. 439-447, 2020. https://doi.org/10.1007/s00709-019-01448-1

LICHTENTHÄLER, H. K. Chlorophylls and carotenoids: pigments of photosynthetic biomembranes. In: PACKER, L.; DOUCE, R. Methods in enzimology. London: Academic Press, 1987. v. 148, p. 350-381.

LIMA, G. S. de; ANDRADE, E. M. G.; KETOUNOU, T. R.; LIMA, V. L. A. de; GHEYI, H. R.; SILVA, S. S. da et al. Photosynthesis, photochemical efficiency and growth of West Indian cherry cultivated with saline waters and nitrogen fertilization. Bioscience Journal, v. 35, n. 1, p. 67-78, 2019a. http://orcid.org/0000-0001-9960-1858

LIMA, G. S. de; PINHEIRO, F. W. A.; DIAS, A. S.; GHEYI, H. R.; SOARES, L. A. dos A.; SILVA, S. S. da. Growth and production components of West Indian cherry cultivated with saline waters and potassium fertilization. Revista Brasileira de Engenharia Agrícola e Ambiental, v. 23, n. 4, p. 250-256, 2019 b. 
MELO, A. S.; SILVA JÚNIOR, C. D. da; FERNANDES, P. D.; SOBRAL, L. F.; BRITO, M. E. B.; DANTAS, J. D. M. Alterações das características fisiológicas da bananeira sob condições de fertirrigação. Ciência Rural, v. 39, n. 3, p. 733-741, 2009. http://dx.doi.org/10.1590/S0103-84782008005000101

MENDES, B. S. S.; WILLADINO, L. G.; CUNHA, P. C. da; OLIVEIRA FILHO, R. A. de; CAMARA, T. R. Mecanismo fisiológicos e bioquímicos do abacaxi ornamental sob estresse salino. Revista Caatinga, v. 24, n. 3, p. 71-77, 2011.

SÁ, F. V. da S.; GHEYI, H. R.; LIMA, G. S. de; PAIVA, E. P. de; LACERDA, C. F.; FERNANDES, P. D. Saline water, nitrogen and phosphorus on water relations and physiological aspects of West Indian cherry. Comunicata Scientiae, v. 9, n. 3, p. 430437, 2018b. https://doi.org/10.14295/cs.v9i3.2781

SÁ, F. V. da S.; GHEYI, H. R.; LIMA, G. S. de; PAIVA, E. P. de; MOREIRA, R. C. L.; SILVA, L. de A. Water salinity, nitrogen and phosphorus on photochemical efficiency and growth of West Indian cherry. Revista Brasileira de Engenharia Agrícola e Ambiental, v. 22, n. 3, p. 158-163, 2018a. http://dx.doi.org/10.1590/1807-1929/agriambi.v22n3p158-163

SÁ, F. V. da S.; GHEYI, H. R.; LIMA, G. S. de; PAIVA, E. P. de; SILVA, L. de A.; MOREIRA, R. C. L. et al. Ecophysiology of West Indian cherry irrigated with saline water under phosphorus and nitrogen doses. Bioscience Journal, v. 35, n. 1, p.211-221. 2019. http://dx.doi.org/10.14393/BJ-v35n1a2019-41742

SCHOLANDER, P. F.; HAMMEL, H. T.; HEMMINGSEN, E. A.; BRADSTREET, E. D. Hydrostatic pressure and osmotic potentials in leaves of mangroves and some other plants. Proceedings of the National Academy of Science, v. 52, n. 1, p. 119-125, 1965.

SILVA, A. R. A.; BEZERRA, F. M. L.; LACERDA, C. F. de; SOUSA, C. H. C. de; CHAGAS, K. L. Pigmentos fotossintéticos e potencial hídrico foliar em plantas jovens de coqueiro sob estresses hídrico e salino. RevistaAgro@mbiente On-line, v. 10, n. 4, p. 317-325, 2016. http://dx.doi.org/10.18227/1982-8470ragro.v10i4.3650

SOUSA, J. R. M. de; GHEYI, H. R.; BRITO, M. E. B.; SILVA, F. de A. F. D. da; LIMA, G. S. de. Dano na membrana celular e pigmentos clorofilianos de citros sob águas salinas e adubação nitrogenada. Irriga, v. 22, n. 2, p. 353-368, 2017. https://doi.org/10.15809/irriga.2017v22n2p353-368

TAIZ, L.; ZEIGER, E.; MOLLER, I. M.; MURPHY, A. Fisiologia e desenvolvimento vegetal. 6. ed. Porto Alegre: Artmed, 2017. 858p.

WEATHERLEY, P. E. Studies in the water relations of the cotton plant. I. The field measurement of water deficits in leaves. New Phytologist, v. 49, n. 1, p. 81-97, 1950. 